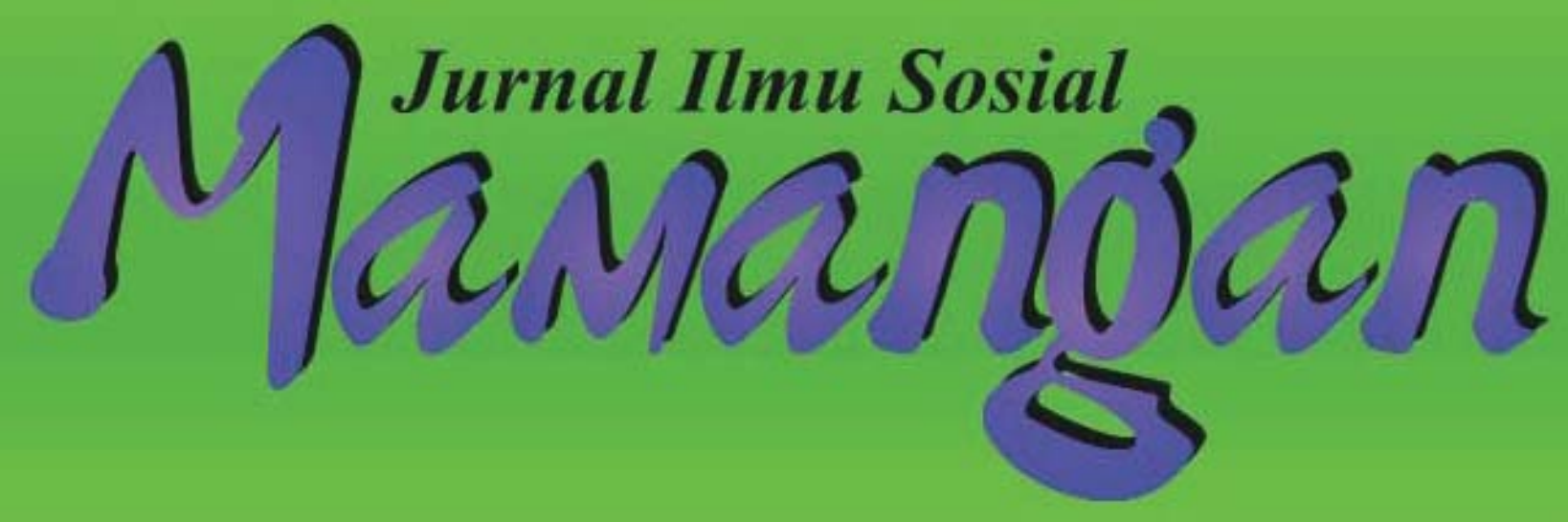

Beberapa Hipotesis Tentang Eksklusi Sosial di Indonesia Robert M.Z. Lawang

Dapatkah Indonesia Bebas Dari Kutukan Kolonial?

Refleksi Kritis Atas MP3EI

Noer Fauzi Rachman \& Dian Yanuardy

Rontoknya Dominasi Negara di Tambang Batu Bara Ombilin Sawahlunto

Zaiyardam Zubir \& Zulqayyim

Protes Korban Bencana; Studi Konflik Penanggulangan Bencana di Pasar Raya Padang

Firdaus

Peran Perempuan dalam Resolusi Konflik Rehabilitasi dan Rekonstruksi Pasar Raya Padang Ira Ariesta

Resolusi Konflik Berbasis Adat; Studi Resolusi Konflik Harta Pusaka Tinggi di Nagari Gantuang Ciri, Kab. Solok, Sumatera Barat

Yuhelna

Nelayan Vs Rentenir; Studi Ketergantungan Nelayan terhadap Rentenir pada Masyarakat Pesisir Delmira Syafrini 


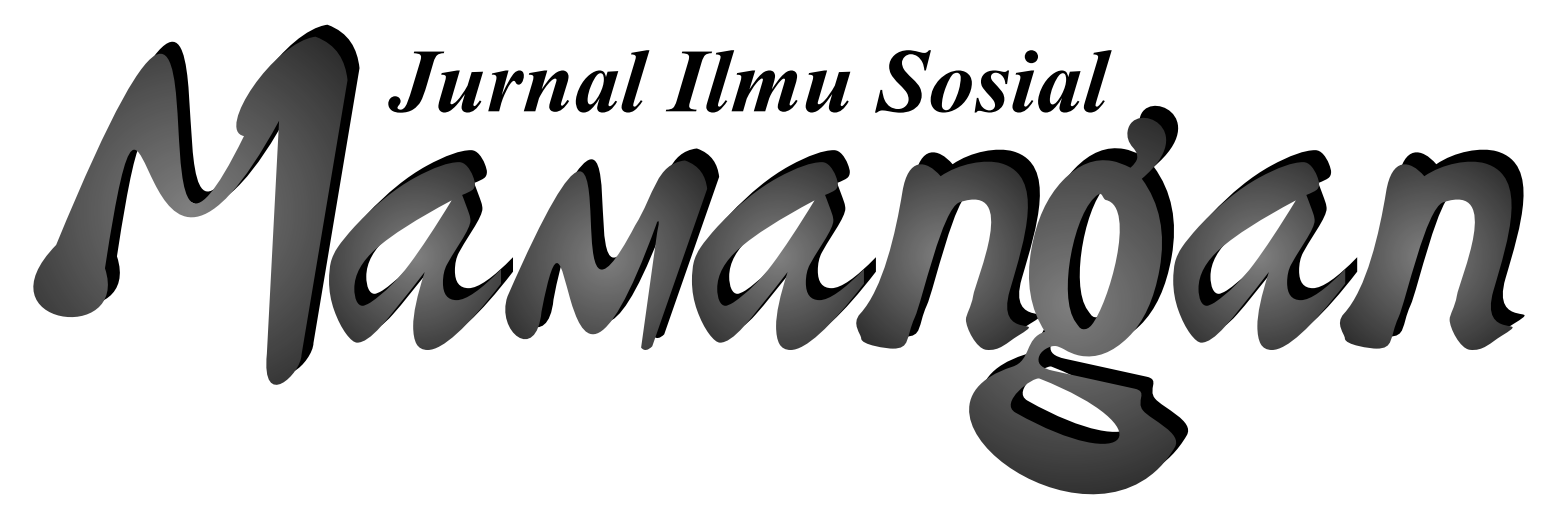




\section{Mitra Bestari}

Prof. Dr. Afrizal, MA. (FISIP, Unand Padang)

Prof. Dr. Badaruddin, M. Si. (FISIP, USU Medan)

Dr. A. Latief Wiyata, M. Si. (Universitas Jember, Jember)

Dr. Fikarwin Zuska, M. Si. (FISIP, USU Medan)

Nurus Shalihin, M. Si., Ph.D. (Fak. Ushuluddin IAIN Imam Bonjol Padang)

Dr. Semiarto A. Purwanto, M. Si. (FISIP, UI Jakarta)

Dr. Wahyu Wibowo, M. Si. (Universitas Nasional, Jakarta)

\section{Dewan Redaksi}

Dr. Zusmelia, M. Si.

Dr. Maihasni, M. Si.

Firdaus, S. Sos., M. Si.

\section{Pemimpin Redaksi/Editor}

Firdaus, S. Sos., M. Si.

\section{Anggota Redaksi}

Dian Kurnia Anggreta, S. Sos., M. Si.

Rinel Fitlayeni, S. Sos., MA.

Rio Tutri, M. Si

Sri Rahayu, M. Pd

Surya Prahara, SH,. MH.

Yuhelna, MA.

ISSN: 2301-8496

viii +81 halaman, $21 \times 29 \mathrm{~cm}$

\section{Alamat Redaksi:}

Laboratorium Program Studi Pendidikan Sosiologi, STKIP PGRI Sumbar Kampus STKIP PGRI, Jl. Gunung Pangilun, Padang, Sumatera Barat

Email: redaksimamangan@yahoo.com \& daus_gila@yahoo.com

\section{Penerbit:}

Laboratorium Program Studi Pendidikan Sosiologi, STKIP PGRI Sumbar

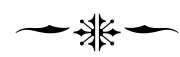




\section{PENGANTAR REDAKSI}

K onflik dalam masyarakat merupakan keniscayaan. Ia akan terus menjadi bagian dalam dinamika kemasyarakatan dan mengejawantah dalam berbagai bentuk yang secara garis bersar dikategorikan sebagai bentuk laten dan bentuk manifest. Pola dan bentuk konflik juga terus mengalami perkembangan sesuai dengan tingkat perkembangan masyarakat dimana konflik tersebut ada. Pola dan bentuk itu, mulai dari yang sederhana hingga yang paling 'canggih' dan bahkan disengaja ada untuk kepentingan tertentu oleh kelompok tertentu.

Meskipun para penganut fungsionalisme meganggap bahwa konflik dalam kehidupan sosial adalah abnormal (Johnson, 1994:161), namun konflik di lain kesempatan merupakan fakta sosial yang bisa fungsional bagi struktur tertentu selama ia dikelola dengan baik. Maka konflik kemudian di beberapa kesempatan juga dibutuhkan untuk kepentingan-kepentingan tertentu. Sehingga dengan demikian, adakalanya konflik mengikuti polanya sendiri dan adakalanya seirama dengan perkembangan masyarakat.

Menyadari bahwa perkembangan masyarakat terus melaju ke bentuk yang lebih kompleks, dan asumsi bahwa konflik juga akan kompleks sesuai dengan perkembangan kompleksitas masyarakat, Mamangan Edisi II yang ada di tangan pembaca ini mengambil konflik sebagai tema umum. Dalam edisi ini konflik dilihat oleh penulis dalam berbagai dimensi melalui berbagai pendekatan, baik secara teoritis maupun empiris melalui studi lapangan. Beberapa pakar di bisangnya telah menyumbang dalam dalam edisi kedua ini.

Tulisan pertama disumbangkan oleh Prof. Robert Lawang yang mendiskusikan konsep eksklusi sosial dalam konteks sosial, ekonomi dan politik. Tiga ranah ini menurut Lawang dikuasai arus utama (main stream) yang tidak mudah dimasuki oleh kelompok sosial tertentu dalam masyarakat paling bawah (underclass), sehingga mereka mengalami deprivasi. Selain itu, Lawang juga menyebut adanya perbedaan pandangan dan cara menjelaskan gejala sosial yang terkait eksklusi sosial. Meskipun konsep eksklusi sosial adalah konsep Barat, namun di Indonesia menurut Lawang, eksklusi sosial terjadi dalam berbagai struktur sosial masyarakat, baik di perkotaan maupun di pedesaan. 
Tulisan kedua disumbangkan oleh Noer Fauzi Rachman dan Dian Yanuardy yang mengupas secara kritis MP3EI. Dalam tulisannya, Fauzi dan Dian mempreteli skema MP3EI dan menyebutnya sebagai bagian dari upaya untuk memperdalam integrasi tanah air Indonesia ke dalam zona perdagangan bebas ASEAN dan Asia Timur. menurut mereka MP3EI pada pokoknya bertumpu pada upaya untuk melakukan reorganisasi ruang dalam rangka memperlancar interaksi dan aliran kapital, barang dan tenaga kerja untuk aktivitas produksi-konsumsi. Skema MP3EI dalam pola pemberian lisensi pada perusahaan untuk mengeksploitasi Sumber daya Alam menurutnya tidak jauh berbeda dengan kebijakan pemerintah kolonial Belanda sejak 1870, yang menempatkan Indonesia sebagai tempat produksi komoditas global.

Tulisan ketiga disumbangkan oleh Zayardam Zuber dan Zulqayim tentang rontoknya dominasi negara di Tambang Batubara Omblin, Sawahlunto. Zayardam dan Zulqayim dalam tulisannya mengemas sejarah beralihnya tambang di Kota Sawahlunto dari tangan perusahaan ke tangan rakyat yang selama puluhan tahun hanya menjadi penonton di arena tambang. Proses peralihan tersebut menurut Zayardan dan Zulqayim antara lain dilatari oleh penguasaan terhadap lahan di sekitar tambang yang dikuasi oleh dua kelompok, yaitu masyarakat adat dan pemerintah daerah. Selain itu, menurunnya aktivitas tambang PT. BA-UPO selaku BUMN yang kemudian menyerahkan pengurusan tambang kepada Pemda setempat juga menjadi bagian dari latar rontokya dominasi negara.

Tulisan keempat disumbangkan oleh Firdaus yang menguraikan protes korban bencana dalam proses rehabilitasi dan rekonstruksi di Pasar Raya Padang. Firdaus menyebutkan faktor penyebab munculnya protes adalah kebijakan pembangunan yang tidak partisipatif dan merugikan pedagang yang merupakan korban bencana. Kebijakan itu dibuat oleh pemerintah melalui mekanisme yang tidak sesuai dengan aturan yang ada. Protes yang dilakukan oleh korban bencana dilakukan dengan berbagai strategi, mulai dari strategi konfrontasi hingga negosiasi.

Tulisan kelima disumbangkan oleh Ira Ariesta yang mengulas peran perempuan dalam resolusi konflik Pasar Raya Padang. Ulasan Ira 'nyambung' dengan tulisan Firdaus sebelumnya. Jika Firdaus lebih menekankan pembahasan tentang penyebab dan strategi protes, maka Ira lebih menekankan pada resolusi konflik. Resolusi konflik yang dibahas Ira lebih fokus lagi pada peran perempuan. Menurut Ira, peran perempuan dalam proses resolusi konflik di Pasar Raya dilakukan oleh empat aktor utama, yaitu perempuan dari instansi pemerintah, perempuan aktivis LSM (PBHI Sumbar), perempuan aktivis mahasiswa dan perempuan pedagang. Keempat kelompok memainkan peran yang berbeda dalam resolusi konflik, mulai dari aksi massa hingga kegiatan advokasi terorganisir.

Tulisan keenam disumbangkan oleh Yuhelna yang membahas tentang mekanisme penyelesaian konflik harta pusaka tinggi secara adat di Minangkabau. Penyelesaian konflik harta pusaka tinggi di Minangkabau dilihat di nagari Gantuang Ciri. Resolusi konflik dilakukan pada 3 tingkatan. Tingkatan pertama resolusi konflik dilakukan di tingkat suku dengan melibatkan pangulu suku. Tingkat kedua resolusi konflik dilakukan pada tingkat yang lebih luas, yaitu pada institusi Tigo Niniak atau Ampek Niniak. Pada tingkat ini, resolusi konflik difasilitasi oleh niniak mamak masing-masing suku atau kaum yang berkonflik. Pada tingkat ketiga resolusi konflik dilakukan di lembaga adat Kerapatan Adat Nagari (KAN). Resolusi konflik pada tingkat ini difasilitasi oleh pengurus KAN yang merupakan perwakilan dari semua suku yang ada dalam nagari.

Tulisan terakhir, disumbangkan oleh Delmira Syafrini yang menganalisis ketergantungan nelayan dengan tengkulak di wilayah pesisir. Delmira melihat ketergantungan nelayan terhadap rentenir sebagai fenomena yang dilematis. Di satu sisi, nelayan mendapat kemudahan mengakses 
modal, di sisi lain nelayan dirugikan dengan suku bunga yang tinggi. Sementara, lembaga keuangan seperti Bank belum mampu menjadi katup penyelamat karena mekanisme rungguhan yang disyaratkan lembaga ini tidak terjangkau oleh nelayan. Di bagian akhir, Delmira menawarkan pemberdayaan sebagai solusi untuk memutus ketergantungan nelayan terhadap rentenir.

Demikianlah tulisan pada edisi ini, dan kepada para penyumbang tulisan pada edisi ini redaksi mengucapkan terima kasih atas karya intelektual dan buah pemikiran mereka, dan kepada para pembaca, redaksi mengucapkan selamat membaca. 



\section{DAFTAR ISI}

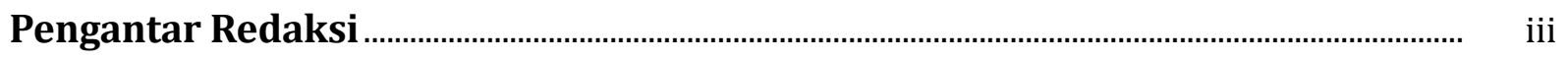

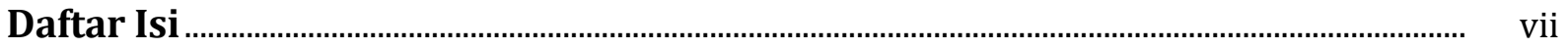

Beberapa Hipotesis Tentang Eksklusi Sosial di Indonesia

Robert M.Z. Lawang

Dapatkah Indonesia Bebas Dari Kutukan Kolonial?

Refleksi Kritis Atas MP3EI

Noer Fauzi Rachman \& Dian Yanuardy

Rontoknya Dominasi Negara di Tambang Batu Bara Ombilin Sawahlunto

Zaiyardam Zubir \& Zulqayyim

Protes Korban Bencana; Studi Konflik Penanggulangan Bencana di

Pasar Raya Padang

Firdaus

Peran Perempuan dalam Resolusi Konflik Rehabilitasi dan Rekonstruksi

Pasar Raya Padang

Ira Ariesta

Resolusi Konflik Berbasis Adat; Studi Resolusi Konflik Harta Pusaka Tinggi di Nagari Gantuang Ciri, Kab. Solok, Sumatera Barat

Yuhelna

Nelayan Vs Rentenir; Studi Ketergantungan Nelayan terhadap Rentenir pada Masyarakat Pesisir

Delmira Syafrini .

Profil Penulis. 



\title{
RESOLUSI KONFLIK BERBASIS ADAT Studi Resolusi Konflik Harta Pusaka Tinggi di Nagari Gantuang Ciri, Kab. Solok, Sumatera Barat
}

\author{
Yuhelna \\ (Dosen Program Studi Pendidikan Sosiologi, STKIP PGRI Sumatera Barat) \\ 一非—
}

\begin{abstract}
Conflict of harta pusaka tinggi is a kind of conflict often occurs in Minangkabau. The Court of Sumatera Barat issued a circular to solve 'sako' and 'pusako' conflict by custom mechanism. This article explain harta pusaka tinggi conflict resolution base on institution Minangkabau custom mechanism and effectiveness. Specifically this article explain step and mechanism of conflict resolution of harta pusaka tinggi base on institution of Minangkabau custom and effectiveness to solve harta pusaka tinggi problem.
\end{abstract}

Kata Kunci : Resolusi konflik, Harta Pusaka Tinggi, Adat.

\section{Pengantar}

Minangkabau merupakan salah satu bentuk kebudayaan yang ada di Indonesia. Sistem kebudayaannya termasuk kebudayaan yang unik dibandingkan dengan daerah lain di Indonesia. Hal ini disebabkan, pertama karena masyarakat Minang memadukan adat dengan agama. Terkenal dengan adagium "adat basandi syarak, syarak basandi kitabullah" (adat berdasarkan agama Islam, agama Islam berdasarkan $\mathrm{Al}$ Quran).Kedua sistem kekerabatan yang lazim ada di Indonesia adalah sistem patrilineal yang garis keturunannya menurut bapak (laki-laki) sedangkan masyarakat Minangkabau dengan sistem matrilineal yang garis keturunannya menurut ibu (perempuan).
Prinsip sistem kekerabatan matrilineal yang dianut masyarakat Minangkabau adalah matrilineal descend, dalam hal ini ada beberapa prinsip yang diperhitungkan yaitu : a) Keturunan dihitung dari garis keturunan ibu, artinya segala macam hak dan kewajiban dalam keluarga hanya diperhitungkan melalui garis keturunan ibu, b) suku dihitung menurut garis keturunan ibu, c) exogami, perkawinan yang terjadi harus berasal dari luar suku, d) perkawinan bersifat matrilokal artinya suami mendatangi atau bertempat tinggal di rumah istrinya, dan ia tidak menjadi anggota kelompok kerabat istrinya, e) harta dan gelar pusaka diwariskan dari mamak kepada kemenakan, f) anggota-anggota kelompok kerabat semuanya merasa bersaudara kandung, senasib, sehina, semalu. Mendapat malu salah 
seorang anggota keluarga itu, berarti juga malu bagi anggota keluarga lainnya (Firman, 1997:2).

Di Minangkabau dalam menjalankan kehidupan kekerabatan kaum atau suku dilakukan secara sederhana. Disini peranan ibu begitu kuat dalam melaksanakan kegiatan masyarakat, baik dalam hal perkawinan, pewarisan atau pengaturan harta pusaka (Romi, 2010:1). Harta pusaka dalam masyarakat Minangkabau dibagi dua yakni harta pusaka rendah dan harta pusaka tinggi. Warisan yang ditinggalkan seseorang, pada tingkat pertama disebut sebagai harta pusaka rendah (biasanya warisan yang berasal dari orang tua). Oleh karena warisannya masih dalam jumlah kecil, ahli warisnya dapat membuat kesepakatan untuk mengelola harta warisan itu, umpamanya untuk dijual atau dibagi-bagi di antara mereka, tindakan menjual ini termasuk tindakan tidak terpuji. Disamping itu karena orang yang mewarisannya masih sedikit, maka statusnya masih dipandang rendah. Akan tetapi, apabila para ahli waris tetap menjaga keutuhan warisan itu dan kemudian pada gilirannya mewariskan pula kepada ahli warisnya, sehingga tidak mudah lagi mengadakan kesepakatan untuk pengelolaannya, maka statusnya telah dipandang sebagai pusaka tinggi (Navis, 1984:163).

Harta pusaka tinggi ialah segala harta pusaka yang diwarisi secara turun temurun dari mamak kepada kemenakan yang ada dalam satu suku. Ketentuan adat Minangkabau tentang pewarisan harta pusaka tinggi ini berbunyi sebagai berikut:

Biriek biriek tabang kasasak

Dari sasak turun ka halaman

Dari niniek turun ka mamak

Dari mamak turun ka kamanakan

Ketentuan adat Minangkabau tentang pewarisan ini, dimana ahli warisnya (penerima warisan) itu adalah kemenakan (Amir, 2011:20). Proses pemindahan kekuasaan atas harta pusaka tinggi dari mamak kepada kemenakan dalam istilah adat disebut juga dengan "pusako basalin" (Manggis, 1982:93). Salah satu pusaka tinggi berbentuk tanah (dikenal dengan tanah ulayat), sistem pewarisannya diturunkan kepada anak perempuan secara turun temurun dan pengelolaannya secara bersama-sama. Tapi beberapa tahun belakangan ini, di Sumatera Barat intensitas konflik menyangkut kepemilikan tanah ulayat cukup tinggi (Fitlayeni, 2009:4).

Di Minangkabau tidak ada orang yang mau menjual harta pusaka tinggi seperti tanah atau sawah, karena harta pusaka tinggi kepemilikannya adalah secara kolektif dimiliki oleh masyarakat kaum atau dalam masyarakat Minangkabau disebut orang sasuku (dimiliki oleh satu suku secara bersama). Pameo masyarakat Minangkabau mengatakan: dijua tak dimakan bali, digadai tak dimakan sando (dijual tak dimakan beli, digadai tak dimakan sandera). Apabila harta pusaka tinggi hendak dipindahtangankan atau digadaikan, harus mendapatkan kesepakatan dari kaum yang diwakili oleh ninik mamak. ${ }^{1}$

Namun pada saat sekarang ini pewarisan itu juga mengalami kekaburan, karena masingmasing individu dalam suku yang sama dalam hal ini adalah sekaum, mereka semua merasa berhak dalam menyandang gelar adat tersebut. Sehingga dengan demikian muncul perselisihan yang menyebabkan terjadinya konflik. Dalam aturan adat Minangkabau disaat sako sudah dipegang oleh seseorang, maka harta pusako juga secara langsung menjadi hak individu yang mewarisi sako tersebut (Fitlayeni, 2009.6).

Di Sumatera Barat, khusus yang terkait dengan persoalan adat istiadat atau yang lebih dikenal dengan harato pusako, termasuk jenis sengketa yang paling banyak diajukan di pengadilan. Persentasenya diperkirakan mencapai 90\% (KPI Sumbar: 2006). Selain dari segi jumlah yang tergolong besar, kasus yang berdimensi adat ini, juga tergolong kasus yang memiliki tingkat kerumitan yang tinggi. Biasanya disebabkan oleh rumitnya memahami dan

1. Niniak Mamak dalam struktur adat Minangkabau adalah pimpinan adat. 
mengurai struktur adat, terutama bagi hakimhakim yang tidak memahami adat dan budaya Minangkabau.

Konflik harta pusaka merupakan salah satu bentuk konflik dalam konteks lokal, sehingga dalam penyelesaiannya juga dibutuhkan pada sumber-sumber lokal juga. Kerapatan Adat Nagari (KAN) merupakan sebuah lembaga pemerintahan nagari yang anggota-anggotanya terdiri dari unsur ninik mamak sebagai pemangku adat yang mewakili kaum dan sukunya. Keberadaan KAN potensial untuk berperan dalam penyelesaian sengketa konflik harta pusaka di Minangkabau. Peranan KAN merupakan salah satu bentuk penyelesaian yang dilakukan secara lokal.

Penyelesaian konflik harta pusaka di Minangkabau yang dilakukan oleh lembaga adat sangat berbeda dengan apa yang dilakukan oleh penyelesaian yang dilakukan oleh pengadilan. Dalam kasus konflik tidak semua bisa diselesaikan dengan hukum positif, karena konflik harta pusaka membutuhakan pengetahuan tentang silsilah dari harta pusaka yang disengketakan. Oleh karena itu peran KAN sebagai lembaga adat yang ada di Minangkabau sangat memilki arti penting. Penyelesaian dengan menggunakan lembaga KAN sebagai tempat penyelesaian merupakan bentuk penyelesaian konflik dengan menggunakan hukum adat. Dengan demikian peradilan adat ini masih eksis karena masyarakat adat tetap mempertahankannya serta mematuhi keputusan peradilan adat tersebut.

\section{Tinjauan Pustaka}

Penelitian yang pernah dilakukan dan sekaligus memberikan inspirasi tulisan ini antara lain pernah dilakukan oleh Rinel Fitlayeni (2010). Dalam penelitiannya, Fitlayeni menemukan bahwa terjadinya penyimpangan harta pusaka tinggi dipengaruhi perubahan struktur keluarga dimana peran mamak dalam memimpin kehidupan keluarga saparuik adalah sebagai kepala suku yang menjadi sumber bagi kesejahteraan anggota keluarga, namun disisi lain ia juga berperan sebagai kepala keluarga (sumando). Dengan demikian terjadi peralihan fungsi kepemimpinan dari mamak ke sumando, tentu saja merubah fungsi dan tanggung jawab memiliki pengaruh dalam kehidupan dalam masyarakat. Perubahan yang dirasakan oleh masyarakat sekarang ini lebih cendrung menuju pada terjadinya proses individualisme. Akibatnya banyak ditemukan praktek penyimpangan terhadap harta pusaka tinggi oleh mamak.

Penelitian lainnya dilakukan oleh Eldawati (2004). Penelitian Eldawati menemukan bahwa eksistensi harta pusaka tinggi apabila digadaikan menurut ketentuan yang diperbolehkan oleh hukum adat Minangkabau adalah jika terjadi kasus rumah gadang katirisan(rumah gadang ketirisan) yaitu biaya memperbaiki rumah gadang yang telah rusak, gadih gadang alun balaki(gadis dewasa belum bersuami), yaitu biaya persiapan dan pelaksanaan perkawinan seorang gadis yang biasaanya mahal karena penjamuan yang berlarut-larut., mayat tabujuah diateh rumah.(mayat terbujur di atas rumah). Upacara kematian seorang kaum yang dihormati harus sama agungnya dengan upacara perkawinan atau penobatan penghulu. Upacara berlangsung bertahap-tahap, seperti pada waktu tiga hari, tujuh hari, tiga kali tujuh hari, empat puluh hari, seratus hari dan akhirnya tiga kali seratus hari. Setiap upacara senantiasa mengadakan kenduri makan minum. Sedangkan faktor-faktor yang menyebabkan terjadinya penyimpangan gadai terhadap harta pusaka tinggi adalah karena bermacam-macam kebutuhan mendesak seperti untuk modal usaha, kebutuhan hidup sehari-hari dan kebutuhan lainnya.

Penelitian lainnya pernah dilakukan oleh Salahuddin (2002).Penelitian Salahuddin menyebutkan bahwa Setawar Sedingin merupakan sebuah model resolusi konflik yang memiliki mekanisme kerja hampir sama dengan konsiliasi yang umum dikenal dalam literatur konflik.Setawar Sedingin sebagai sebuah 
model resolusi konflik menunjukkan bahwa keberhasilan sebuah model resolusi konflik lokal untuk tereproduksi dan ditarik pada tingkat konflik etnik.Rasa kemanusiaan ternyata telah menjadi faktor penentu dari lahirnya kesatuan pandangan dalam menerima Setawar Sedingin sebagai sebuah model resolusi konflik.Persamaan penelitian ini dengan tulisan hasil penelitian ini adalah sama-sama melihat resolusi konflik dengan menggunakan mekaisme adat dan yang menjadi perbedaan dari penelitian ini adalah objeknya adalah masyarakat yang terlibat dalam konflik harta pusaka tinggi di Minangkabau.

Selain tinjauan pustaka di atas, dalam tulisan ini penulis juga menggunakan pendekatan fungsionalisme konflik Coser untuk melakukan analisis, dimana konflik memiliki fungsi positif terhadap pihak-pihak yang berkonflik.Coser melihat konflik sebagai mekanisme perubahan sosial dan penyesuaian, dapat memberi peran positif, atau fungsi positif dalam masyarakat. Sehingga dalam suatu hubungan sosial tertentu, konflik yang disembunyikan tidak akan memberi efek positif (Novri, 2009:54).

Secara umum, konflik dapat diartikan sebagai sebuah kondisi dimana terjadi ketegangan sebagai akibat dari kepentingan yang saling bertentangan atau berbeda.Dalam tataran sosiologi, konflik dapat terjadi baik antara individu ataupun kelompok. Menurut Coser, konflik dipandang dan diperlukan sebagai sesuatu yang mengacaukan atau disfungsional terhadap keseimbangan sistem secara keseluruhan. Konflik tidak seharusnya merusak atau disfungsional untuk sistem dimana konflik itu terjadi dan konflik juga memiliki konsekuensi-konsekuensi positif atau mengutamakan dalam sistem tersebut (Johnson, 1990: 195)

Fungsi positif konflik menurut Coser, yang paling jelas dalam dinamika kelompok - dalam (in-group) versus hubungan kelompok - luar (out-group). Kekuatan solidaritas internal dan integrasi kelompok - dalam dapat bertambah tinggi karena tingkat permusuhan dengan kelompok - luar bertambah besar, kekompakan yang semakin tinggi dari satu kelompok yang terlibat dalam konflik membantu memperkuat batas antara kelompok yang satu dengan kelompok lainnya dalam lingkungan tersebut dan mereka tidak peduli apakah penyebab konflik itu realistis atau tidak (Johnson, 1990: 197).

Konflik dapat merupakan proses yang bersifat instrumental dalam pembentukan, penyatuan, dan pemeliharaan struktur sosial. Konflik dapat menetapkan dan menjaga garis batas antara dua atau lebih kelompok.Katup penyelamat (safety-valve) ialah salah satu mekanisme khusus yang dapat dipakai untuk mencegah konflik soaial.Katup penyelamat membiarkan luapan permusuhan tersalur tanpa menghancurkan seluruh struktur, konflik membantu "membersihkan suasana" dalam kelompok yang sedang kacau. Coser melihat katup penyelamat demikian berfungsi sebagai "jalan keluar yang meredakan permusuhan", yang tanpa itu hubungan-hubungan di antara pihakpihak yang bertentangan akan semakin tajam. Dengan demikian praktek-praktek atau institusi katup penyelemat memungkinkan pengungkapan rasa tidak puas terhadap struktur (Poloma, 2010:107-108).

Sebagaimana yang dikatakan oleh Coser (Poloma, 2010), lewat katup penyelamat (safety-valve) itu permusuhan dihambat agar tidak berpaling melawan obyek aslinya. Tetapi penggantian yang demikian mencakup juga biaya bagi sistem sosial maupun individu: mengurangi tekanan untuk menyempurnakan sistem untuk memenuhi kondisi-kondisi yang sedang berubah maupun membendung ketegangan dalam diri individu, menciptakan kemungkinan tumbuhnya ledakan-ledakan destruktif.

Peran dari safety valve yang dikemungkan oleh Coser (Poloma, 2010) sebagai salah satu mekanisme khusus yang dapat dipakai untuk mencegah konflik sosial.Katup penyelamat 
membiarkan luapan permusuhan tersalur tanpa menghancurkan seluruh struktur, konflik membantu "membersihkan suasana" dalam kelompok yang sedang kacau.Hal ini yang bisa kita lihat dari peran KAN dalam masyarakat Minangkabau sebagai sebuah lembaga yang membatu menyelesaiakan konflik harta pusaka tinggi yang sering terjadi.

\section{Metode Penelitian}

Penelitian ini menggunakan pendektan studi kasus yang bercirikan kualitatif.Jenis ini ditempuh bukan karena suatu kasus mewakili kasus-kasus yang lain atau karena menggambarkan sifat atau problem tertentu, namun karena, dalam seluruh aspek kekhususan dan kesederhanaannya, kasus itu sendiri menarik minat (Stake, 2009:301).

Datadalam penelitian ini adalah hasil wawancara dan pengamatan terhadap informan di Nagari Gantuang Ciri Kabupaten Solok yang pernah mengalami konflik harta pusaka tinggi dan lembaga yang menjadi sarana dalam penyelesaian konflik harta pusaka tinggi di Minangkabaumelalui pengamatan dan wawancara tidak terstruktur terhadap informan, berbagai data yang dapat dianalisis untuk mengetahui tipologi konflik, prosedur dan mekanisme resolusi konflik, kelebihan dan kelemahan resolusi konflik harta pusaka tinggi di Minangkabau.

\section{Resolusi Konfliklokal di Minangkabau: Aktor, Peran \&Tahapan}

Dalam resolusi konflik harta pusaka tinggi di Minangkabau yang menjadi aktorutamanya adalah ninik mamak yang sekaligus merupakan anggota Kerapatan Adat Nagari(KAN).Peran ninik mamak dalam resolusi konflik adalah sebagai mediator antara dua kelompok yang bermasalah. Proses resolusi konflik harta pusaka tinggi di nagari Gantuang Ciriterdiri dari tiga tahapan.
Dalam proses resolusi konflik, selain sebagai mediator, ninik mamak juga mencari informasi terkait dengan harta pusaka yang menyebabkan terjadinya konflik. Tiga tahap resolusi konflik harta pusaka tinggi yang ada di nagari Gantuang Ciri berdasarkan pengalaman masyarakat yang pernah mengalami konflik adalah sebagai berikut:

\section{Resolusi konflik dalam suku}

Proses resolusidalam suku dilakukan oleh ninik mamak yang ada di dalam suku tersebut. Teknik resolusidimulai dari individu yang meminta kepada mamaktungganai untuk menyampaikan kepada ninik mamak bahwa kemenakannya minta tolong untuk menyelesaikan konflik yang sedang ia hadapi. Dalam resolusitersebut juga ada syarat-syarat yang harus dipenuhi seperti membayar uang adat senilai 1 emas $(2,5$ gram) danmembawa sirih dan carano. Langkah pertama yang dilakukan adalah pihak yang sedang berkonflik dalam hal ini adalah pihak yang menggugat menyampaikan kepada mamaktungganai tentang maksud dan tujuannya yang ingin melakukan gugatan terkait dengan sako yang dipakai oleh keluarga saparuikyang lain. Mamak tungganai juga harus menanyakan alasan-alasan yang bisa diterima untuk mengajukan gugatan tersebut.Setelah itu mamak tungganai menemui ninik mamak yang ada dalam suku untuk meminta menyelesaikan konflik yang sedang terjadi dengan memberikan alasan yang bisa diterima oleh ninik mamak. Alasan itu hanya disampaikan secara lisan oleh mamak tungganai.

Ninik mamak yang ada di dalam suku terdiri dari penghulu ${ }^{2}$, malin $^{3}$, manti $^{4}$ dan dubalang ${ }^{5}$ Setelah ada kata sepakat dari ninik

\footnotetext{
2. Penghulu adalah pemimpin di dalam suku

3. Malin adalah pembantu penghulu yang membidangi agama

4. Manti adalah pembantu penghulu yang melaksanakan kebijakan

5. Dubalang adalah pembantu penghulu dalam menjaga ketertiban dan keamanan
} 
mamak dalam suku untuk menyelesaikan konflik tersebut, maka secara resmi pihak ninik mamak meminta kepada pihak yang menggugat mengirim surat kepada ninik mamak dalam suku. Surat ini bertujuan untuk memberitahukan kepada KAN dan Wali Nagari bahwa ada kasus yang akan mereka selesaikan di dalam suku mereka.

Disaat surat diterima oleh ninik mamak dalam suku, langkah selanjutnya adalah merundingkan kasus yang diajukan oleh anggota sukunya tersebut apakah layak untuk diproses atau tidak. Setelah ada keputusan dari ninik mamak, barulah mamak tungganai dipanggil kembali untuk menyampaikan keputusan dari ninik mamak bahwa kasus tersebut bisa mereka proses karena alasan yang disampaikan oleh pihak penggugat bisa diterima oleh ninik mamak yang ada di dalam suku.

Waktu yang sudah disepakati untuk resolusi konflik di dalam suku adalah 1 tahun (12 bulan). Waktu 12 bulan merupakan standar maksimal yang sudah disepakati oleh pengurus KAN. Resolusi konflik yang dilakukan di dalam suku memiliki waktu yang lama karena KAN mengharapkan pengoptimalan resolusi konflik tersebut di dalam suku. Hal ini disebabkan karena pihak yang paling paham dengan konflik yang terjadi tersebut adalah ninik mamak dari individu yang berkonflik, sehingga jalan resolusi yang akan diambil juga memiliki pertimbangan untuk kelangsungan hidup bermasyarakat bagi individu yang berkonflik itu nantinya.

Proses yang dilakukan oleh ninik mamak yang ada di dalam suku adalah memanggil pihak yang berkonflik untuk menanyakan tentang konflik yang sedang mereka alami. Selain itu ninik mamak juga mencari informasi-informasi lain dari anggota suku yang mengetahui konflik seperti apa sudut pandang dari anggota suku yang mengetahui kasus tersebut. Hal ini bertujuan sebagai pedoman bagi ninik mamak dalam mencari resolusi konflik tersebut.Setelah itu ninik mamak juga mencari ranji (silsilah) yang berkaiatan dengan sako atau gelar adat yang menjadi penyebab konflik.

Waktu satu tahun penyelesain konflik di dalam suku merupakan waktu maksimal. Apabila dalam jangka waktu 1 (satu) tahun tersebut, belum juga ada keputusan yang diberikan oleh ninik mamak dalam suku, maka secara otomatis dilimpahka kepada tahap selanjutnya yaitu 3 suku atau 4 suku.Resolusi yang dilakukan dalam suku merupakan tahap resolusi yang paling sulit karena harus mencari asal usul dari harta pusaka yang dikonflikkan.

Resolusi yang dilakukan dalam suku tidak hanya berjalan sendiri saja seperti apa yang diinginkan oleh ninik mamak, tetapi juga ada pengawasan yang dilakukan oleh KAN sebagai lembaga adat yang ada dalam nagari. Fungsi KAN sekaligus untuk melihat sejauh mana perkembangan dari resolusi konflik yang sedang mereka lakukan.Disaat KAN mengetahui ninik mamak yang ada dalam suku tidak menjadikan hal ini sebagai prioritas karena kasibukan yang mereka miliki, KAN akan menegur dengan cara mengirim surat kepada ninik mamak yang isinya adalah untuk segera menyelesaiakan konflik yang sedang dialami oleh anggota sukunya. Setelah ada keputusan yang diberikan oleh ninik mamak yang ada di dalam suku terkait konflik yang menimpa anggota sukunya, pihak yang berkonflik bisa menerima keputusan tersebut atau tidak menerima keputusan tersebut.Bagi pihak yang tidak bisa menerima keputusan tersebut bisa melanjutkan kembali resolusinya ke tahap selanjutnya dengan alasan-alasan yang bisa di terima oleh pihak tersebut. 


\section{Resolusi Konflik di Tigo Niniak ${ }^{6}$ atau Ampek Niniak ${ }^{7}$}

Proses resolusi konflik di Tigo Niniak atau Ampek Niniak merupakan proses yang kedua dari tingkatan resolusi konflik di nagari Gantuang Ciri. Resolusi di tingkat ini baru bisa dilakukan apabila sudah ada keputusan dari ninik mamak yang di dalam suku, tapi salah satu pihak tidak bisa menerima dari keputusan tersebut maka ia berhak melanjutkan ke tingkat Tigo Niniak atau Ampek Niniak dengan catatan alasan yang mereka sampaikan kepada pihak Tigo Niniak atau Ampek Niniak bisa diterima. Untuk syarat lain yang harus dipenuhi juga sama dengan resolusidi dalam suku.

Proses resolusi konflik harta pusaka tinggi melalui Tigo Niniak atau Ampek Niniak juga memiliki syarat-syarat yang tidak jauh berbeda dengan proses resolusi yang dilakukan di dalam suku. Hal yang pertama dilakukan adalah menyampaikan niatannya kepada mamaktungganai bahwa ia merasa tidak puas dengan hasil keputusan yang disepakati oleh ninik mamak yang ada dalam suku, sehingga ia ingin melanjutkan proses resolusinya melalui Tigo Niniak atau Ampek Niniak. Dengan demikian Mamak tungganai akan menyampaikan kepada pihak Tigo Niniak atau Ampek Niniak tentang maksud dan tujuannya tersebut.

Pihak Tigo Niniak atau Ampek Niniak akan menanyakan terlebih dahulu alasan yang membuat mereka tidak bisa menerima keputusan dari ninik mamak dalam suku. Hal ini akan menjadikan pertimbangan oleh pihak Tigo Niniak atau Ampek Niniak untuk bisa menyelesaikan konflik tersebut. Setelah alasan yang dikemungkakan, maka

6. Istilah Tigo Niniak adalah istilah untuk menyebut tiga buah suku yang ada di nagari gantuang Ciri. Tiga suku tersebut adalah suku Piliang, suku Caniago, suku Jambak

7. Istilah Ampek Niniak adalah istilah untuk menyebut empat buah suku yang ada di nagari gantuang Ciri. Empat suku tersebut adalah sukuTanjuang, suku Guci, suku Bendang, suku Melayu ninik mamak yang ada dalam Tigo Niniak atau Ampek Niniak akan memusyawarahkan terlebih dahulu alasan yang disampaikan oleh pihak yang tidak puas dengan hasil keputusan ninik mamak yang ada di dalam suku. Karena butuh pembahasan yang mendalam untuk menerima permintaan pihak yang tidak bisa menerima keputusan ninik mamak yang ada di dalam suku tersebut.

Di Nagari Gantuang Ciri resolusi konflik harta pusaka tinggi jarang yang ada dilakukan di Tigo Niniak atau Ampek Niniak. Hal ini diungkapkan oleh ketua KAN Jasril Bila Sati pada tanggal 21 November 2011 jam 07:30 Wib di Gantuang Ciri:

\footnotetext{
"konflik harta pusaka tinggi yang terjadi di nagari gantuang ciri sangat jarang sekali diselesaiakan melalui Tigo Niniak atau Ampek Niniak, selama saya menjadi ketua KAN malahan belum ada satupun konflik yang diselesaiakan di Tigo Niniak atau Ampek Niniak"
}

Walaupun demikian tetap saja ada prosedur yang dibuat oleh KAN untuk melanjutkan resolusi konflik melalui Tigo Niniak atau Ampek Niniak. Diantaranya adalah memberikan uang adat sebanyak 1 emas (2,5 gram) kepada pihak Tigo Niniak atau Ampek Niniak. Uang adat digunakan oleh pihak Tigo Niniak atau Ampek Niniak sebagai pembeli kopi dan juga untuk biaya transportasi.Selain itu juga menyerahkan sirih dan carano (tempat yang digunakan untuk menarok sirih).Hal memiliki arti bahwa bentuk penghormatan kepada ninik mamak yang ada di dalam suku.Waktu yang sudah disepakati untuk lamanya resolusi konflik tersebut adalah selama 6 bulan sebagai waktu maksimal untuk masalah itu bisa diselesaiakan.Pihak yang terlibat dalam resolusi masalah tersebut juga mencari informasi dari berbagai sumber yang bisa dijadikan sebagai bahan rujukan dalam resolusi konflik tersebut. 
Sumber informasi yang juga bisa digunakan oleh pihak Tigo Niniak atau Ampek Niniak adalah hasil temuan dari ninik mamak dalam suku dan juga informasi yang didapatkan langsung oleh Tigo Niniak atau Ampek Niniak. Setelah keputusan dikeluarkan oleh Tigo Niniak atau Ampek Niniak tentang resolusi sengketa harta pusaka tinggi, pihak yang menggugat boleh menerima keputusan tersebut atau tidak. Karena tidak ada paksaan untuk menerima keputusan tersebut dari pihak manapun. Dari masing-masing pihak baik yang menggugat atau pun yang digugut memiliki hal yang sama terhadap keputusan yang sudah dikeluarkan oleh Tigo Niniak atau Ampek Niniak. Puas atau tidak puas dengan keputusan tersebut. Disaat salah satu dari pihak merasa tidak puas dengan keputusan tersebut, maka ia berhak untuk melanjutkan lagi ke proses selanjutnya yaitu resolusi yang dilakukan oleh lembaga kerapatan adat nagari (KAN).

Resolusi konflik yang dilakukan di Tigo Niniak atau Ampek Niniak merupakan bagian dari mekanisme resolusi konflik sebagai kantup penyelamat, karena pihakpihak yang terlibat dalam resolusi konflik merupakan bagian dari anggota KAN Nagari Gantuang Ciri. Proses yang dilakukan juga sama dengan resolusi yang dilakukan di dalam suku, namun yang membedakan adalah pihak atau individu yang terlibat dalam penyelesainya adalah ninik mamak dari suku lain.

Resolusi konflik harta pusaka tinggi melalui Tigo Niniak atau Ampek Niniak juga merupakan bagian dari peran lembaga KAN. Tigo Niniak atau Ampek Niniak sebagai bentuk dari safety valve yang dikemukankan oleh Coser (Poloma, 2004:108) yang berfungsi sebagai jalan keluar yang meredakan permusuhan. Resolusi yang dilakukan di Tigo Niniak atau Ampek Niniak ninik juga bagian dari proses yang dilakukan melalui mekanisme adat.

\section{Resolusi konflik di lembaga} Kerapatan Adat Nagari (KAN)

Proses resolusiyang dilakukan di KAN merupakan muara terakhir dalam resolusi konflik harta pusaka tinggi melalui nilai dan institusi adat. Setelah ada keputusan dari Tigo Niniak atau Ampek Niniak terhadap konflik yang mereka selesaikan dan ternyata salah satu dari pihak yang berkonflik tidak bisa menerima keputusan tersebut, maka ia berhak untuk melanjutkan proses penyelesaiannya di KAN apabila alasan yang mereka sampaikan bisa diterima oleh KAN. Dan syarat yang harus dipenuhi sama dengan tahap sebelumnya.

Untuk melanjutkan proses resolusi konflik harta pusaka tinggi melalui KAN, pihak yang merasa tidak puas dengan keputusan dari Tigo Niniak atau Ampek Niniak mengirim surat kepada KAN untuk menyelesaiakan konflik yang sedang mereka hadapi. Setelah pihak KAN menerima surat tersebut, anggota KAN melakukan rapat terlebih dahulu untuk membahas pengajuan yang disampaikan oleh pihak penggugat tersebut. Ada kesepakat dari anggota KAN untuk memproses konflik tersebut barulah pihak yang menggugat dipanggil kembali oleh KAN untuk memenuhi syarat-syarat yang harus dipenuhi yaitu sirih dengan cerano, karih, dan uang adat senilai 1 emas (2,5 gram).

Kegunaan dari uang adat yang dibayarkan oleh pihak yang menggugat kepada KAN juga sama fungsinya dengan uang adat yang di bayarkan disaat resolusi konflik melalui dalam suku dan Tigo Niniak atau Ampek Niniak yaitu sebagai uang untuk pembeli kopi dan transportasi. Uang pembeli kopi ini sebenarnya hanya sebagai sebuah ungkapan penggati dari uang jasa. Hal ini terjadi karena dalam masyarakat Minangkabau untuk mengungkapkan sesuatu 
itu tidak boleh secara langsung tapi harus dengan bahasa lain. Menyerahkan sirih dan caro juga memiliki fungsi sebagai tanda penghormatan kepada KAN sebagai sebuah lembaga adat yang ada dalam nagari.

Setelah pihak yang menggugat tersebut mememenuhi syarat-syarat tersebut barulah KAN mulai memproses konflik tersebut. Dalam resolusi konflik harta pusaka tinggi, KAN membentuk tim resolusi konflik harta pusaka tinggi yang jumlahnya disesuiakan dengan jenis konflik yang diajukan. Jumlah anggota tim yang dibentuk jumlahnya ganjil mulai dari 5, 7 dan 9 orang. Tim yang dipilih berasal dari ninik mamak berasal dari suku yang berbeda dari pihak yang menggugat, sehingga bisa diharapkan mereka bisa memberikan penilain yang objektif dalam melakukan proses resolusi tersebut. Jumlah tim yang berbeda tersebut tergantung kepada besar atau kecil konfliknya.

Waktu yang diberikan oleh pihak KAN untuk resolusi konflik tersebut adalah selama 6 bulan batas waktu maksimal.Tim yang sudah dibentuk harus bisa menyelesaikan konflik tersebut dengan waktu yang sudah ditentukan oleh KAN. Dalam proses resolusi tersebut KAN juga melakukan pemantauan, karena KAN juga harus tahu bagaimana perkembangan dari resolusiya tersebut. Setelah proses resolusi konflik tersebut mendapatkan hasil dari tim resolusi konflik, maka hasil tersebut juga dimusyawarahkan kembali oleh seluruh anggota KAN.

Musyawarah yang dilakukan di KAN bertujuan untuk melihat apakah ada kecurangan-kecurangan yang terjadi dalam proses resolusi tersebut. Berkemungkinan ada peluang untuk munculnya suap terhadap tim yang resolusi konflik harta pusaka tinggi yang sudah dibentuk, karena tim yang di bentuk dalam penyelesain konflik tersebut berasal dari suku yang berbeda dari individu yang berkonflik. Oleh sebab itu KAN selalu memusyawarahkan kembali hasil yang sudah didapatkan oleh tim. Setelah musyawarah barulah hasilnya disampaikan kepada pihak berkonflik.

Proses resolusi konflik di KAN tidak terlalu banyak terjadi karena pihak KAN lebih mengutamakan resolusi yang dilakukan di dalam suku. Hal juga yang disampaikan oleh ketua KAN Jasril Bila Sati tanggal 1 Desember 2011 jam 20.00 Wib di Gantuang Ciri: "di nagari gantuang ciri kami lebih
mengutamakan resolusi dalam suku karena
bagaimanapun juga mereka yang di dalam
sukulah yang paling tahu dengan masalah
yang mereka hadapi dan bagaimana jalan
keluar yang baik, kami di KAN hanya
memantau bagaimana jalannya proses
resolusinya"

Konflik yang saat ini yang diselesaikan oleh KAN Nagari Gantuang Ciri adalan konflik-konflik yang masih ada di KAN waktu kepengurusan KAN sebelumnya, sehingga secara langsung pengurus KAN yang menjabat sekarang yang memiliki tugas untuk menyelesaikan konflik yang masih belum ada resolusinya tersebut. Hal ini terjadi karena tidak optimalnya peranan dari penguruskan yang sebelumnya sehingga masih banyak kasus konflik harta pusaka tingggi dan juga gelaran adat yang belum diselesaikan.

Salah satu konflik harta pusaka tinggi yang diselesaikan oleh KAN adalah konflik harta pusaka tinggi yang terjadi di suku piliang dengan suku melayu. Perebutan atas kepemilikan sawah yang dikuasai oleh suku piliang, tetapi suku melayu mengatakan bahwa sawah tersebut sebenarnya adalah milik suku melayu dan mereka miliki buktibukti kepemiliki sawah tersebut sedangkan suku piliang juga mengatakan mereka memiliki bukti atas kepemiliki sawah tersebut.Kekaburan terhadap asal usul harta pusaka tinggi membuat masing suku seperti 
piliang dan melayu merasa sama-sama memiliki hak atas sawah tersebut.

Proses resolusi yang dilakukan oleh KAN adalah memanggil kedua belah pihak untuk meminta bukti masing-masing tentang kepemiliki harta pusaka tinggi tersebut. Dalam resolusinya KAN membentuk tim resolusi yang terdari 5 orang tim yang berasal dari suku bendang, tanjuang, guci, caniago dan jambak.

Tim yang dibentuk diambil dari ninik mamakyang merupakan anggota KAN. Waktu resolusi yang dibutuhkan untuk menyelesaikan kasus tersebut adalah 6 bulan.Hasil yang diputuskan oleh KAN adalah bahwa harta pusaka tinggi dalam bentuk sawah tersebut merupakan milik dari suku melayu. Hal ini diputuskan karena tim resolusi konflik tersebut menemukan bukti ada surat gadai yang diberikan oleh suku melayu bahwa nenek moyong suku melayu pernah menggadaikan sawah tersebut kepada suku piliang.

Namun sawah tersebut bisa diolah kembali dan menjadi miliki suku melayu kembali dengan catatan pihak dari suku melayu harus menebuh gadai yang sudah dilakukan oleh nenek moyangnya kepada suku piliang sesuai dengan nilai gadai yang tertera dalam surat tersebut dengan hitungan berapa sukat padi. Keputusan tersebut dapat diterima oleh kedua belah pihak dengan tidak merugikan salah satu dari pihak yang berkonflik.

Resolusi konflik harta pusaka tinggi yang dilakukan melalui mekanisme adat yang dilakukan oleh KAN adalah sebuah proses resolusi konflik melibatkan peran dari sebuah lembaga yang diakui keberadaannya dalam masyarakat. KAN sebagai sebuah lembaga adat yang ada di Minangkabau yang memiliki tugas dalam menyelesaikan konflik harta pusaka tinggi yang terjadi di Minangkabau menggunakan mekanisme yang lebih mengutamakan musyawarah dan mufakat.
Dalam kenyataan yang ditemukan di lapangan setiap konflik yang terjadi baik harta pusaka tinggi dan juga gelaran adat kebanyakan diselesaikan di dalam suku.Hal ini terjadi karena ninik mamak yang ada di Nagari Gantuang Ciri dan juga merupakan anggota KAN, mengharapkan resolusi konflik dioptimalkan di dalam suku.

\section{Efektifitas Resolusi Konflik Lokal Minangkabau}

Dalam pengalaman penyelesaian konflik pusako tinggi di Gantuang Ciri, jarang ada pihak yang menggugat atau yang digugat yang tidak menerima keputusan dan melanjutkan ke tahap selanjutnya, yaitu Tigo Niniak atau Ampek Niniak. Hal ini di ungkapakan oleh Subari Datuak Ampang Basa pada tanggal 21 November 2011 jam 20.30 Wib di Gantuang Ciri:

\footnotetext{
"keputusan dari dalam suku bisa diterima oleh pihak yang menggugat karena keputusan yang diambil adalah gelar pusaka yang diperebutkan tersebut digilirkan pemberiannya kepada pihak yang berkonflik dalam memperebutkan gelar tersebut, sehingga tidak merugikan kedua belah pihak"
}

Walaupun jarang dari pihak yang berkonflik yang tidak mau menerima keputusan yang telah diputuskan oleh ninik mamak yang ada di dalam suku, tapi masih ada juga yang tidak bisa menerima keputusan tersebut dan ingin melanjutkan ke tahap selanjutnya yaitu Tigo Niniak atau Ampek Niniak. Disaat mereka mengajukan agar ada resolusi dari pihak Tigo Niniak atau Ampek Niniak, pihak Tigo Niniak atau Ampek Niniak akan mencari informasi terlebih dahulu sebelum menyatakan kesiapannya untuk memprosesnya. Di Nagari Gantuang Ciri sangat jarang pihak Tigo Niniak atau Ampek Niniak yang mau memproses kasus yang sudah diselesaikan dalam suku, karena mereka melihat apa yang sudah menjadi keputusan dari ninik mamak yang ada di dalam suku sudah tepat. 
Selebihnya, dalam kasus konflik antara mamak dan kemenakandalam kasus mamak menggadaikan harta pusaka tinggi tanpa persetujuan kemenakan, Ninik mamak lah yang menjadi perantara dalam proses resolusi tersebut.KAN menolak untuk menyelesaiakan konflik tersebut dan lebih menyarankan untuk diselesaikan di keluarga. Dalam hal ini KAN mengacu pada pepatah minangkabau yang berbunyi kusuik kusuik bulu ayam paruaih juo nan ka manyalasaikan(kusut-kusut bulu ayam, paruh yang menyelesaiakan) yang berarti apapun masalah yang terjadi dalam sebuah keluarga tetap resolusiya dari keluarga tersebut. Hal ini diungkapkan oleh ketua KAN Nagari Gantuang Ciri Jasril Bila Sati:

\begin{abstract}
"konflik yang terjadi antara mamak dan kemenakan diselesaiakan di dalam suku karena hal tersebut merupakan aib dari sebuah keluarga sehingga kami dari KAN tidak mau untuk menyelesaiakan masalah tersebut dan lebih menyarankan diselesaikan secara kekeluargaan"
\end{abstract}

Konsep resolusi konflik harta pusaka tinggi di Gantuang Ciri tetap berpegang pada pola awak samo awak, yang artinya bahwa yang bersengketa adalah saudara sendiri. Oleh karena itu, kebijaksanaan bertolak pada usaha bagai maelo rambuik dalam tapuang, rambuik ndak putuih, tapuang ndak taserak (mennarik rambut dari tepung, rambut tidak putus, tepung tidak tumpah). Maksudnya, bila keputusan yang diambil, diharapkan persengketaan baru tidak sampai tumbuh, atau keputusan yang diambil diharapakan tidak sampai menimbulkan kesengsaraan (Navis,1984:116). Resolusi yang dilakukan di dalam suku merupakan bagian dari mekanisme untuk menyelematakan kelompok masyarakat Gantuang Ciri dari dari konflik sosial. Hal ini merupakan bagian dari peran dan fungsi KAN sebagai katup penyelamat karena ninik mamak yang ada di dalam suku juga merupakan bagian dari anggota KAN. Ninik mamak yang ada di dalam suku merupakan perwakilan dari masing-masing suku yang ada di Nagari Gantuang Ciri.
Dengan adanya resolusi konflik harta pusaka tinggi berbasis adat memiliki kelebihan dan kelemahan. Dari 5 kasus konflik harta pusaka tinggi yang terjadi di Nagari Gantuang Ciri hanya 1 kasus yang sampai ke pengadilannegeri. Beberapa kelebihan yang dirasakan oleh individu yang mengalami konflik adalah:

\section{Biaya murah}

Proses resolusi konflik harta pusaka tinggi berbasis adat lebih sedikit mengeluarkan biaya dibandingkan dengan pengadilan negeri. Biaya yang dikeluarkan hanya membayar uang adat senilai 1 emas (2,5 gram) kepada pihak yang terlibat dalam resolusi konflik tidak sebanyak yang di pengadilan negeri. Hal ini di umgkapkan oleh datuak basa "bahwa biaya penyelesasian yang di lakukan di pengadilan lebih mahal karena banyak dana yang dikeluarkan seperti uang transportasi ke pengadilan dan sewa pengacara"

\section{Peluang terjadinya korupsi, kolusi dan nepotisme kecil}

Peluang terjadi KKN sangat kecil karena resolusi yang dilakukan melalui tahapan manapun selalu dilakukan kontrol oleh anggota KAN terhadap resolusi konflik tersebut.Aktor yang terlibat dalam penyelesaian konflik tidak terlalu banyak sehingga mudah melacak apabila terjadinya suap kepada ninik mamak yang terlibat dalam penyelesaian konflik.

\section{Resolusi konflik dilakukan dengan sistem musyawarah.}

Resolusi konflik lebih mengutamakan sistem musyawarah karena dalam resolusi konflik tersebut ninik mamak tidak ingin merugikan salah satu dari pihak yang berkonflik dan juga tidak menggunakan konsep menang kalah seperti yang ada di pengadilan negeri.

Kelemahan yang dirasakan adalah kurangnya SDM dari ninik mamak dari segi kualitas seperti kurangnya pengetahuan tentang 
adat dan rendahnya tingkat pendidikan seperti SD dan SMP membuat kurangnya rasa kepercayaan dari masyarakat akan kemampuan mereka dalam resolusi konflik tersebut, tidak adanya perhatian pemerintah seperti pemberian gaji kepada ninik mamak yang ada di KAN dan belum adanya dukungan resmi dari pemerintah seperti perda terhadap resolusi konflik yang berbasis adat.

\section{Kesimpulan}

Resolusi konflik harta pusaka tinggi bisa berjalan efektif dalam kehidupan masyarakat Minangkabau apabila ada dukungan penuh yang diberikan oleh pemerintah terhadap KAN sebagai lembaga yang dipercaya untuk menyelesaikan konflik yang terjadi dalam Nagari. Mengutip dari apa yang disebutkan oleh Lewis Coser (Poloma, 2010) tentang safety valve,maka fungsi KAN sebagai katup penyelemat dalam resolusi konflik merupakan sebuah mekanisme yang bisa mempertahakan kehidupan masyarakat dari konflik yang berkelanjutan. Konflik harta pusaka tinggi di Minangkabau itu akan selalu ada disebabkan harta pusaka merupakan suatu hal yang tidak bisa dipisahkan dari masyarakat Minangkabau. Keberadaan KAN akan berfungsi sebagai katup penyelemat ketika pemerintah dan masyarakat benar-benar menerapkan keberadaan KAN sebagai tonggak pengatur konflik harta pusaka tinggi yang akan muncul.

KAN dapat menjadi jalan keluar atau solusi penyelesaian permusuhan yang timbul akibat pertentangan antar individu karena harta pusaka tinggi.Keberadaan KAN menjadi alternatif resolusi konflik diluar struktur sosial yang berlaku, dalam hal ini seperti resolusi konflik melalui hukum positif yang ada di pengadilan negeri.Resolusi konflik harta pusaka tinggi merupakan bentuk kearifan lokal yang ada di Minangkabau.Cara-cara yang dilakukan dalam resolusi konflik mengandung nilai-nilai lokal sehingga kearifan lokal ini memberikan manfaat pada pelestarian budaya adat Minangkabau.
Oleh karena kemampuan dan efektifitas KAN dalam penyelesaian konflik pusaka tinggi, perlu bagi pemerintah untuk mengoptimalkan potensi yang sudah ada tersebut dengan

meningkatkan sumber daya manusia ninik mamak yang ada di Minangkabau.Lembaga Kerapatan Adat Minangkabau (LKAM) sebagai lembaga induk juga diharapkan memberikan himbauan kepada semua KAN yang ada disemua nagari di Sumatera Barat untuk melakukan pendampingan dengan optimal yang sifatnya berkelanjutan.Di level kebijakan, hendaknya pemerintah provinsi melahirkan peraturan daerah yang mengatur penyesaian konflik harta pusaka tinggi di Sumatera Barat dengan mengarusutamakan peran KAN.

\section{Daftar Pustaka}

Amir, M.S, 2003. Adat Minangkabau Pola dan Tujuan Hidup Orang Minangkabau. PT. Mutiara Sumber Widya: Jakarta.

2011. Pewarisan Harta Pusaka Tinggi dan Pencaharian. Citra Harta Prima: Jakarta

Davidson, S, Jamie, dkk, 2010. Adat Dalam Politik Indonesia, Yayasan Pustaka Obor Indonesia: Jakarta.

Eldawati, 2004. Eksistensi Harta Pusaka Tinggi Yang Digadaikan Menurut Hukum Adat Minangkabau (Sumatera Barat). Tesis Program Studi Kenotariatan Hukum Universitas Gadjah Mada, Yogyakarta.

Firman, 1997. Adaptasi Fungsi Mamak Dalam Masyarakat Matrilineal Di Minangkabau Dengan Semakin Menonjolnya Keluarga Samande Dibandingkan Keluarga Saparuik. (Studi Pada Masyarakat Rao-rao Kecamatan Sungai Tarab Kabupaten Tanah Datar). Disertasi Program Pasca Sarjana Universitas Airlangga. Surabaya.

Poloma, Margaret, 2010. Sosiologi Kontemporer, Jakarta. 
Johnson, Doyle Paul, 1990. Teori Sosiologi Klasik dan Modern 2 .PT. Gramedia Pustaka Utama. Jakarta.

Maggis, M. Rasjid, 1982. Minangkabau; Sejarah Ringkas Dan Adat. Jakarta: Mutiara.

Navis, A.A. 1983. Alam Takambang Jadi Guru, Adat dan Kebudayaan Minangkabau. Jakarta: Grafitri Press.

Fitlayeni, Rinel, 2009. Pengaruh Perubahan Struktur Keluarga Terhadap Penyimpangan Harta Pusaka Tinggi di Minangkabau. Tesis Jurusan Sosiologi UGM.

Afadarma, Romi, 2010. Peranan Ketua Adat dan Kerapatan Adat Nagari Dalam Penyelesaian
Sengketa Harta Pusaka Tinggi di Nagari Sungai Tarab Kabupaten Tanah Datar Provinsi (Sumatera Barat). Tesis Program Studi Kenotariatan Hukum Universitas Diponegoro.

Salahuddin, 1999. Setawar Sidingin: Sebuah Model Resolusi Konflik Masyarakat Adat di Bengkulu. Tesis Jurusan Sosiologi UGM.

Susan, Novri, 2009, Sosiologi Konflik dan Isu-Isu Konflik Kontemporer. Jakarta : Kencana

Syarifuddin, Amir, 1984, Pelaksanaan Hukum Kewarisan Islam dalam Lingkungan Adat Minangkabau. Jakarta: Gunung Agung, 
